Research Article

\title{
Decomposition of the Methylene Blue Dye Using Layered Manganese Oxide Materials Synthesized by Solid State Reactions
}

\author{
M. E. Becerra, ${ }^{1,2,3,4,5}$ A. M. Suarez $\mathbb{D D}^{3,5}$ N. P. Arias $\mathbb{D D}^{4,6}$ and O. Giraldo $\mathbb{D}^{1,3,4}$ \\ ${ }^{1}$ Departamento de Física y Química, Facultad de Ciencias Exactas y Naturales, Universidad Nacional de Colombia, \\ Sede Manizales 170003, Colombia \\ ${ }^{2}$ Departamento de Ingeniería Química, Facultad de Ingeniería y Arquitectura, Universidad Nacional de Colombia, \\ Sede Manizales 170003, Colombia \\ ${ }^{3}$ Laboratorio de Materiales Nanoestructurados y Funcionales, Facultad de Ciencias Exactas y Naturales, \\ Universidad Nacional de Colombia, Sede Manizales 170003, Colombia \\ ${ }^{4}$ Grupo de Investigación en Procesos Químicos, Catalíticos y Biotecnológicos, Universidad Nacional de Colombia, \\ Sede Manizales 170003, Colombia \\ ${ }^{5}$ Departamento Química, Facultad de Ciencias Exactas y Naturales, Universidad de Caldas, Manizales 17003, Colombia \\ ${ }^{6}$ Facultad de Ciencias e Ingeniería, Universidad de Boyacá, Sogamoso, Colombia
}

Correspondence should be addressed to O. Giraldo; ohgiraldoo@unal.edu.co

Received 26 February 2018; Accepted 24 June 2018; Published 30 July 2018

Academic Editor: Donald L. Feke

Copyright (C) 2018 M. E. Becerra et al. This is an open access article distributed under the Creative Commons Attribution License, which permits unrestricted use, distribution, and reproduction in any medium, provided the original work is properly cited.

The modulation in the synthesis parameters of layered manganese oxides allowed us to produce materials with different AC conductivities. These conductivities were correlated with the catalytic performance of the materials in the decomposition of methylene blue, as a model of electron transfer reactions. The manganese oxides were prepared by thermal reduction of $\mathrm{KMnO}_{4}$ at $400^{\circ} \mathrm{C}$ and $800^{\circ} \mathrm{C}$ where one sample was heated at $1^{\circ} \mathrm{C} / \mathrm{min}$ and the other was heated at $10^{\circ} \mathrm{C} / \mathrm{min}$. The materials were characterized by atomic absorption, average oxidation states of manganese, $\mathrm{X}$-ray diffraction, thermogravimetric analysis, and scanning electron microscopy. The results indicate that, by increasing the synthesis temperature, both the lamellar arrangement and the crystal size increased, while the $\mathrm{Mn}^{4+}$ amount in the material decreased. Furthermore, it was observed that as the conductivity increases for the materials, the catalytic performance also increases. Therefore, a direct correlation between the conductivity and catalytic performance can be established. For example, the layered manganese oxides material synthesized at $400^{\circ} \mathrm{C}$, using a heating rate of $10^{\circ} \mathrm{C} / \mathrm{min}$, showed the highest AC conductivity and had the best performance in the degradation of methylene blue. Finally, we propose a general mechanism for understanding how manganese oxides behave as catalysts that produce oxidizing species from $\mathrm{H}_{2} \mathrm{O}_{2}$ which degrades methylene blue. Our proposed mechanism takes into consideration the state of aggregation of the catalyst, the availability of $\mathrm{Mn}^{4+}$, and the electrical conductivity.

\section{Introduction}

Today's world requires efficient, clean, and environmentally friendly processes. In this context, manganese oxide base materials are an alternative, since by changing the synthesis parameters it is possible to modulate several characteristics: structure, composition, morphology, and electrical conduction [1-3], among others. These features allow designing materials with applications in the primary and secondary batteries [4], supercapacitors [5], catalytic processes [5-7], and the degradation of dyes [8], among others. A recent critical review [9] accounts for the environmental catalytic applications of the Mn-based oxides and recognizes them as one of the most promising catalysts.

A simple route for obtaining birnessite-type layered manganese oxide is the thermal reduction of $\mathrm{KMnO}_{4}$ [6]. Birnessite consists of $\mathrm{MnO}_{6}$ octahedrons where the $\mathrm{Mn}$ atoms are present as $\mathrm{Mn}^{4+}$ and $\mathrm{Mn}^{3+}$ ions. The presence of $\mathrm{Mn}^{3+}$ ions generates an excess negative charge on the layers, which is offset by cations, commonly $\mathrm{Na}^{+}$or $\mathrm{K}^{+}$, and a monolayer 
of water molecules in the interlayer region $[10,11]$. These materials show ionic conduction, due to the movement of the interlaminar cation, and the electronic conduction of (hopping) electrons in the layers [1-3]. The characterization of manganese oxides by AC conductivity is a nondestructive experimental technique, which can provide relevant information on the potential performance of these materials in redox reactions, which can be a useful tool and easy to apply for the design of heterogeneous catalysts for applications that are likely to spread to several redox reactions.

To correlate the conductivity with the catalytic potential of birnessite in electron transfer reactions, its performance in the degradation of methylene blue (chloride 3,7-bis (dimethylamino)phenothiazine-5-inio) was evaluated as a model reaction. The methylene blue $(\mathrm{MB})$ degradation has been studied widely by using $\mathrm{Mn}$-doped $\mathrm{g}_{-} \mathrm{C}_{3} \mathrm{~N}_{4}$ [12], ferrimagnetic materials [13], nickel oxide nanoparticles [14], $\mathrm{Au} / \mathrm{ZnO}[15]$, and titanium oxides [16, 17], among others. In contrast, few studies report the use of manganese oxides $(\mathrm{MnOx})$ for the $\mathrm{MB}$ degradation. Some of those report the use of hydrogen peroxide as an oxidizing agent to generate the reactive oxygen species (ROS), responsible for degrading $\mathrm{MB}$ up to the mineralization to carbon dioxide, sulfate, and nitrate $[18,19]$.

The reaction mechanisms proposed for the MB degradation using $\mathrm{MnOx}$ and $\mathrm{H}_{2} \mathrm{O}_{2}[19,20]$ suggest a reaction between hydrogen peroxide and the surface of $\mathrm{MnOx}$ giving the formation of ROS mainly singlet oxygen $\left({ }^{1} \mathrm{O}_{2}\right)$ and free radicals such as $\mathrm{OH}^{\bullet}$ and $\mathrm{O}_{2}{ }^{\circ-}$. However, we did not find a general mechanism for electron transfer reactions that consider the catalyst aggregation state, the $\mathrm{Mn}^{4+}$ availability, the reactive oxygen species formation, and electrical conductivity, as relevant features in the catalytic activity of the birnessite materials. In the present study, we propose a general mechanism that considers all the experimental parameters including the conductivity.

\section{Materials and Methods}

2.1. Preparation of the Samples. The samples for this study were synthesized by thermal reduction of $\mathrm{KMnO}_{4}$ (Merck, 99\%) [6] at a heating rate of $1^{\circ} \mathrm{C}$ and $10^{\circ} \mathrm{C} / \mathrm{min}$. The final temperatures were $400^{\circ} \mathrm{C}$ and $800^{\circ} \mathrm{C}$. Once calcinated, the materials were washed with distilled and deionized water (DDW) until the $\mathrm{pH}$ of 9.50 was obtained, and finally, the materials were dried at $60^{\circ} \mathrm{C}$ for 48 hours. The materials obtained are named according to the final synthesis temperature and heating rate as follows: $4 \mathrm{R} 1$ and $8 \mathrm{R} 1$ for the first set and $4 \mathrm{R} 10$ and $8 \mathrm{R} 10$ for the second set.

\subsection{Characterization}

2.2.1. Atomic Absorption Spectroscopy (AA). The elemental analysis was performed on a Thermo Series $S 4$ atomic absorption spectrophotometer. About $100 \mathrm{mg}$ of the sample powder was taken for analysis and dissolved in $10.0 \mathrm{~mL}$ solution of $37 \% \mathrm{HCl}: \mathrm{DDW}$ in a $2: 1$ ratio, and it was then heated to obtain $50 \%$ of the initial volume. $1.0 \mathrm{~mL}$ of lanthanum chloride at $1.0 \%$ was added, and the final volume was adjusted with DDW at $100.0 \mathrm{~mL}$ for $\mathrm{Mn}$ and $\mathrm{K}$ content determination.

2.2.2. Average State of Manganese Oxidation (AOS). The analysis of each sample was performed in duplicate, following the method reported by Glover et al. [21]. Briefly, to determine the total content of $\mathrm{Mn}$, approximately $40 \mathrm{mg}$ of material was dissolved in $10.0 \mathrm{~mL}$ of $37 \% \mathrm{HCl}$ and $10.0 \mathrm{~mL}$ of DDW; then, they were heated until the solution became transparent, and the volume was adjusted to $100.0 \mathrm{~mL}$. $100.0 \mathrm{~mL}$ of a saturated solution of $\mathrm{Na}_{2} \mathrm{P}_{2} \mathrm{O}_{7} \cdot 10 \mathrm{H}_{2} \mathrm{O}$ was added to $10.0 \mathrm{~mL}$ of the prepared sample, the $\mathrm{pH}$ was adjusted to about 7.00 with $37 \% \mathrm{HCl}$, and it was titrated by potentiometry with $\mathrm{KMnO}_{4} 0.101 \mathrm{M}$ up to potential jump higher than $100 \mathrm{mV}$. To determine the available oxygen, approximately $40 \mathrm{mg}$ of the sample was dissolved in $15.0 \mathrm{~mL}$ of a $0.10 \mathrm{M}\left(\mathrm{NH}_{4}\right) \mathrm{Fe}\left(\mathrm{SO}_{4}\right)_{2} \cdot 6 \mathrm{H}_{2} \mathrm{O}$ (FAS) (Merck 98\%) solution acidified with $\mathrm{H}_{2} \mathrm{SO}_{4}$ at $98 \%$ and titrated with $0.101 \mathrm{M}$ $\mathrm{KMnO}_{4}$ until it turned pink. $1.0 \mathrm{~mL}$ of FAS was used as a blank under the same conditions described above. The average oxidation state of manganese was calculated like this $\mathrm{AOS}=($ total moles of $\mathrm{O} /$ total moles of $\mathrm{Mn}) \times 2$.

2.2.3. X-Ray Diffraction (XRD). The XRD patterns from the powdered samples were obtained at room temperature in a Rigaku MiniFlex II diffractometer equipped with a radiation source of $\mathrm{Cu} \mathrm{K \alpha}(\lambda=1.5406 \AA)$ at $30 \mathrm{kV}$ and $15 \mathrm{~mA}$ in the continuous mode. Data were taken from 3 to $70^{\circ}$ in $2 \dot{e}$ with an accuracy of $0.01^{\circ}$ in $2 \dot{e}$ at a scan rate of $0.2^{\circ} / \mathrm{min}$ and a step size of $0.02^{\circ}$ in $2 \theta$. The estimated crystal size was performed using the Debye-Scherrer equation [22]:

$$
T=\frac{0.9 \lambda}{\sqrt{(\mathrm{FWHM})_{\mathrm{M}}^{2}-(\mathrm{FWHM})_{\mathrm{s}}^{2} * \cos \theta}},
$$

where $\lambda$ is the $\mathrm{Cu} \mathrm{Ka}$ radiation and $(\mathrm{FWHM})_{\mathrm{M}}$ and $(\mathrm{FWHM})_{\mathrm{s}}$ are the full-width at half maximum of the more intense diffraction peak in the sample and silicon standard, respectively.

2.2.4. Thermogravimetric Analysis (TGA). Thermogravimetric analysis was performed on a TA Instruments, TGA Q500 model, with a sensitivity of $0.1 \mu \mathrm{g}$, a resolution of $\pm 0.1^{\circ} \mathrm{C}$, and an accuracy of $0.01 \%$. The measurement was doing over approximately $10 \mathrm{mg}$ of the sample and analyzed under $\mathrm{N}_{2}$ with a flow of $100.0 \mathrm{~mL} \cdot \mathrm{min}^{-1}$, in a temperature range of $25^{\circ} \mathrm{C}$ to $800^{\circ} \mathrm{C}$, at a heating rate of $10^{\circ} \mathrm{C} \mathrm{min}^{-1}$.

2.2.5. Scanning Electron Microscopy (SEM). The micrographs of the materials were taken on a QUANTA 250 FEI microscope with a tungsten electron source, with a resolution of $3.0 \mathrm{~nm}$ at $30 \mathrm{kV}$. The samples were deposited on a carbon tape and analyzed in the high vacuum mode with a power voltage range between $10.00 \mathrm{kV}$ and $15.00 \mathrm{kV}$ and magnifications of $10000 x$. 
2.2.6. AC Conductivity at Room Temperature. The AC conductivity of the powder materials was measured at $21^{\circ} \mathrm{C}$ and $50 \%$ relative humidity in accordance with the methodology proposed by Arias et al. [1] in a SOLARTRON 1260 equipment with a SOLARTRON 1296 dielectric interface and a 1296-4A test cell equipped with two bronze electrodes in a parallel arrangement in two-point configuration. The distance between the working and the reference electrodes was $1.57 \mathrm{~mm}$. To prevent border effects and eddy currents, the working electrode, with an effective diameter of $20 \mathrm{~mm}$, has a guard ring. The acquisition of impedance data was performed using the $Z$-plot software version 3.3, in a frequency range of $10 \mathrm{MHz}$ to $0.1 \mathrm{~Hz}$ with a voltage amplitude of $100 \mathrm{mV} \mathrm{rms}$. The analyses were performed in duplicate. For treating the data, a $Z$-view software version 3.3 (Scribner Association) was used.

The real-AC conductivity was found from the impedance data using

$$
\sigma^{\prime}=\left(\frac{d}{A}\right) \frac{Z^{\prime}}{Z^{\prime 2}+Z^{\prime 2}}=\left(\frac{d}{A}\right) * Y^{\prime},
$$

where $d$ is the thickness of the sample $(\mathrm{cm}), A$ is the effective electrode area $\left(\mathrm{cm}^{2}\right), Z^{\prime}$ is the real component of the impedance, $Z^{\prime \prime}$ is the imaginary part of the complex impedance, $d / A$ is the geometric factor of the sample, and $Y^{\prime}$ is the conductance.

2.3. Catalytic Test: Degradation of Methylene Blue. The degradation of methylene blue at room temperature was performed by the method reported by Zhang et al. [19], which is described briefly: $150.0 \mathrm{~mL}$ of methylene blue at $30 \mathrm{ppm}$ and $30.0 \mathrm{mg}$ of the $\mathrm{MnOx}$ material were stirred for 20 minutes, and then $6.8 \mathrm{~mL}$ of $\mathrm{H}_{2} \mathrm{O}_{2}$ at $30 \%$ were added. The concentration of methylene blue was monitored at baseline and in the following reaction times: 15, 30, 60, and 120 minutes. For the tests, two aliquots of $1.0 \mathrm{~mL}$ were taken and centrifuged for 4 minutes at $5000 \mathrm{rpm}$. The concentration of methylene blue was measured by UV-Vis spectroscopy at $\lambda=665 \mathrm{~nm}$.

To determine the effect of the superoxide anion in the degradation of the dye [19], the same reaction was carried out in the presence of $100 \mathrm{mM}$ of gallic acid.

\section{Results and Discussion}

3.1. X-Ray Diffraction (XRD). The diffraction patterns from the set of synthesized materials heated at $1^{\circ} \mathrm{C} / \mathrm{min}$ heating rate (Figure 1(a)) show the characteristic diffraction peak of birnessite-type layered manganese oxide $[6,23]$ around $12.30^{\circ}$ (7.19 $\AA$ ). There were no crystallographic phase changes of the layer structure as it was determined from XRD patterns. However, in the range of $30^{\circ}$ to $70^{\circ}$ (Figure $1(\mathrm{~b})$ ), the characteristic peaks of certain lamellar stacking faults appear in the samples that have been heated to $400^{\circ} \mathrm{C}$. Thus, the presence of diffraction peaks at $36.50^{\circ}, 37.26^{\circ}, 41.98^{\circ}, 65.56^{\circ}$, and $66.90^{\circ}$ in the $4 \mathrm{R} 1$ material has been reported for a turbostratic stacking fault in manganese oxides [24]. In $8 \mathrm{R} 1$, the peaks located at $36.02^{\circ}(2.49 \AA), \quad 38.24^{\circ}(2.35 \AA), 40.88^{\circ} \quad(2.20 \AA), 44.28^{\circ}$ $(2.04 \AA)$, $53.08^{\circ}(1.72 \AA)$, and $65.30^{\circ}(1.42 \AA)$ were characteristic of hexagonal-type birnessite $[24,25]$, and weak peaks at $35.18^{\circ}(2.55 \AA), 37.42^{\circ}(2.40 \AA), 40.06^{\circ}(2.25 \AA), 43.70^{\circ}$

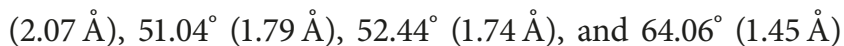
were typical of orthogonal-type birnessite [25]. These changes indicate that the structural order increases as the temperature increases. The XRD patterns for the synthesized materials at $10^{\circ} \mathrm{C} / \mathrm{min}$ heating rate are shown in Figure 1(c). There was no evidence of significant changes in the lamellar arrangement (Figure 1(d)), compared with the materials synthesized at $1^{\circ} \mathrm{C} / \min$ (Figure $1(\mathrm{~b})$ ).

These figures show that materials that were heated at the same temperature have similar structure independent of the rate at which they heated. In contrast, the estimated crystal size was affected by both the synthesis temperature (Table 1) and the heating rate. At higher temperatures and lower heating rate, larger crystal size was obtained.

\subsection{Chemical Composition, Average Oxidation State, Thermal} Stability, and Structural Formulas Determination. As it can be seen in Table 1, the content of $\mathrm{K}^{+}$does not vary significantly in the analyzed samples, whereas the $\mathrm{Mn}^{4+}$ content varies with both the temperature and the heating rate.

In the materials calcined at $800^{\circ} \mathrm{C}$, a lower content of $\mathrm{Mn}^{4+}$ is observed in comparison with those that were calcined at $400^{\circ} \mathrm{C}$. The material $4 \mathrm{R} 10$ showed the highest content of $\mathrm{Mn}^{4+}$. The AOS for $\mathrm{Mn}$ is greater for $4 \mathrm{R} 1$ and $4 \mathrm{R} 10$ than for $8 \mathrm{R} 1$ and $8 \mathrm{R} 10$. These values were also higher than the average oxidation state values reported for birnessite-type materials obtained by low-temperature oxidation-reduction methods $[1,26]$. The thermal reduction of $\mathrm{KMnO}_{4}$ generated materials with higher content of $\mathrm{Mn}^{4+}$ at lower temperatures $[2,27]$. The content of $\mathrm{Mn}^{4+}$ has been reported as a critical surface species in similar materials $[18,19,28-30]$ due to the fact that it initiates the decomposition reactions of $\mathrm{NO} x, \mathrm{SO} x$ [30], and dyes on the surface. Thermal stability studies through TGA showed that the mass losses in the two sets of synthesized materials (Figures 2(a) and 2(b)) up to $150^{\circ} \mathrm{C}$ were associated with physisorbed water, between $150^{\circ} \mathrm{C}$ and $250^{\circ} \mathrm{C}$ with structural water. Finally, for temperatures above $250^{\circ} \mathrm{C}$, the mass losses were associated with a structural change involving the release of oxygen, as it has been reported in previous studies [6]. In general, the thermal stability of the material increases with the synthesis temperature, and no significant differences were observed concerning the heating rate.

With the information obtained by the atomic absorption analysis, the average oxidation, and thermal gravimetric analysis, the different structural formulas were calculated (Table 1) using a modification of the equation reported by Gaillot et al. $[23,31]$ in accordance with the following equation:

$$
\mathrm{K}_{y}^{+}\left(\mathrm{Mn}_{(x-3)}^{4+} \mathrm{Mn}_{(4-x)}^{3+}\right) \mathrm{O}_{[((x+y) / 2)]} \omega \mathrm{H}_{2} \mathrm{O},
$$

where $x$ is the average oxidation state of Mn, $y$ is the K/Mn ratio, and $w$ is the water content calculated from the mass loss of up to $250^{\circ} \mathrm{C}$ under a nitrogen atmosphere.

3.3. Morphological Analysis by Scanning Electron Microscopy (SEM). The morphology of the materials (Figure 3) shows particle aggregates of different sizes, with a sponge morphology. 

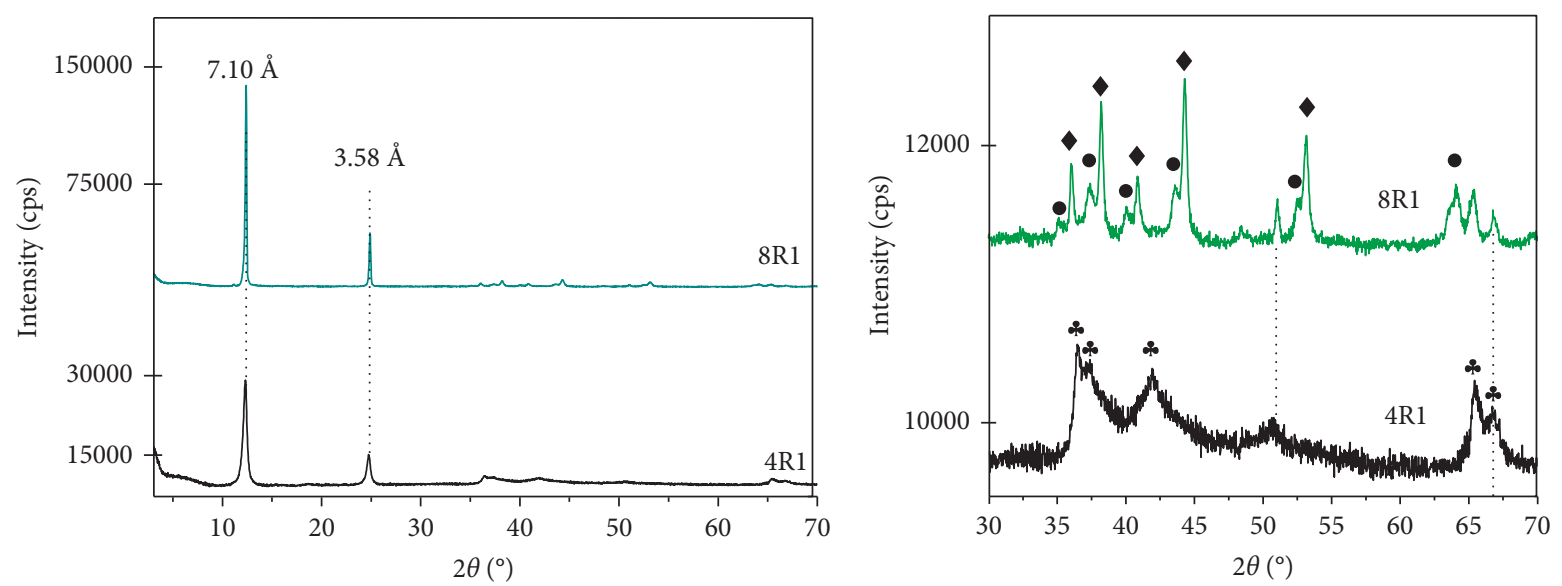

* Turbostratic

- Hexagonal

- Orthogonal

(a)
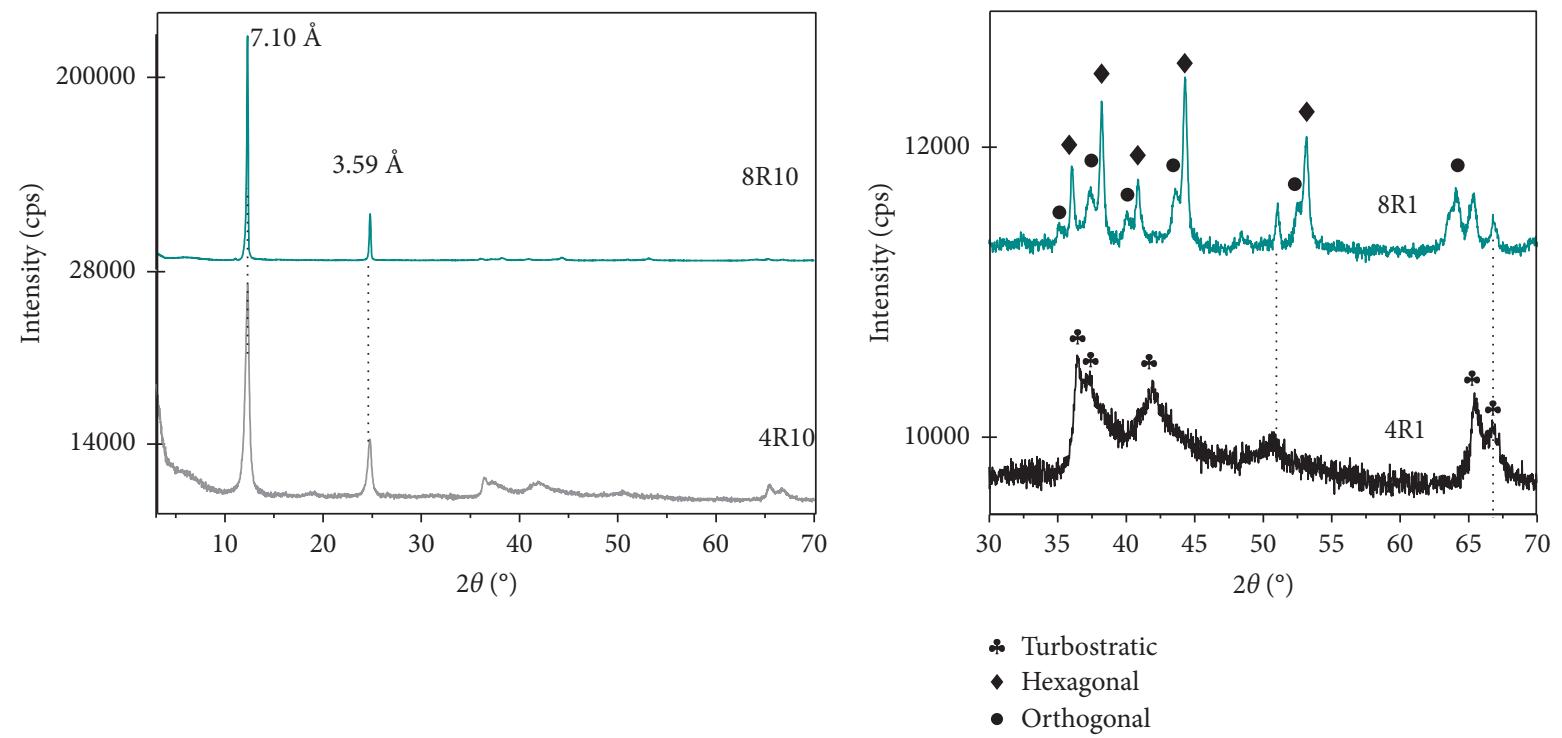

(c)

(d)

Figure 1: X-ray patterns for birnessites synthesized at $400^{\circ} \mathrm{C}$ and $800^{\circ} \mathrm{C}$ : (a) materials at $1^{\circ} \mathrm{C} / \mathrm{min}$ heating rate, (b) zoom between $30^{\circ}$ and $70^{\circ}$

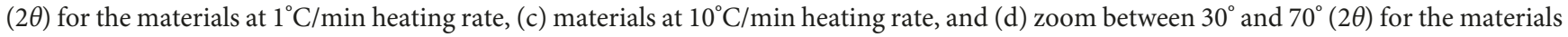
at $10^{\circ} \mathrm{C} / \mathrm{min}$ heating rate.

TABLE 1: Physicochemical parameters and structural formulas of the synthesized materials.

\begin{tabular}{lcccccccc}
\hline Material & $\mathrm{K} / \mathrm{Mn}$ & $\mathrm{AOS}^{\mathrm{a}}$ & $\mathrm{Mn}^{4+}$ & $\mathrm{Mn}^{3+}$ & Structural formula & $\begin{array}{c}\text { Crystal size } \\
(\mathrm{nm})\end{array}$ & $\begin{array}{c}\sigma^{\prime}(\omega) \text { at } 0.1 \mathrm{~Hz} \\
(\mu \mathrm{S})\end{array}$ & $\begin{array}{c}\sigma^{\prime}(\omega) \text { at } 7.94 \mathrm{MHz} \\
(\mu \mathrm{S})\end{array}$ \\
\hline $4 \mathrm{R} 1$ & 0.20 & 3.85 & 0.85 & 0.15 & $\mathrm{~K}_{0.20}^{+}\left(\mathrm{Mn}_{0.85}^{4+} \mathrm{Mn}_{0.15}^{3+}\right) \mathrm{O}_{2.02} 0.660 \mathrm{H}_{2} \mathrm{O}$ & 14 & 5.64 & 21.60 \\
$8 \mathrm{R} 1$ & 0.23 & 3.82 & 0.82 & 0.18 & $\mathrm{~K}_{0.23}^{+}\left(\mathrm{Mn}_{0.82}^{4+} \mathrm{Mn}_{0.18}^{3+}\right) \mathrm{O}_{2.03} 0.512 \mathrm{H}_{2} \mathrm{O}$ & 117 & 2.41 & 16.40 \\
$4 \mathrm{R} 10$ & 0.21 & 3.89 & 0.89 & 0.11 & $\mathrm{~K}_{0.21}^{+}\left(\mathrm{Mn}_{0.89}^{4+} \mathrm{Mn}_{0.11}^{3+}\right) \mathrm{O}_{2.05} 0.660 \mathrm{H}_{2} \mathrm{O}$ & 9 & 13.60 & 41.20 \\
$8 \mathrm{R} 10$ & 0.20 & 3.82 & 0.82 & 0.18 & $\mathrm{~K}_{0.20}^{+}\left(\mathrm{Mn}_{0.82}^{4+} \mathrm{Mn}_{0.18}^{3+}\right) \mathrm{O}_{2.01} 0.592 \mathrm{H}_{2} \mathrm{O}$ & 67 & 1.10 & 12.90 \\
\hline
\end{tabular}

${ }^{a}$ Average oxidation state of $\mathrm{Mn}$.

The larger particles in 8R1 and 8R10 materials take the form of a mesh with different spacings between crystals.

These results showed a relationship between aggregate size and both temperature synthesis and heating rate, as it has been reported for ceramic materials like perovskites [32]. The morphological changes were consistent with the increase in the crystal size as it was estimated by the XRD (Table 1). 


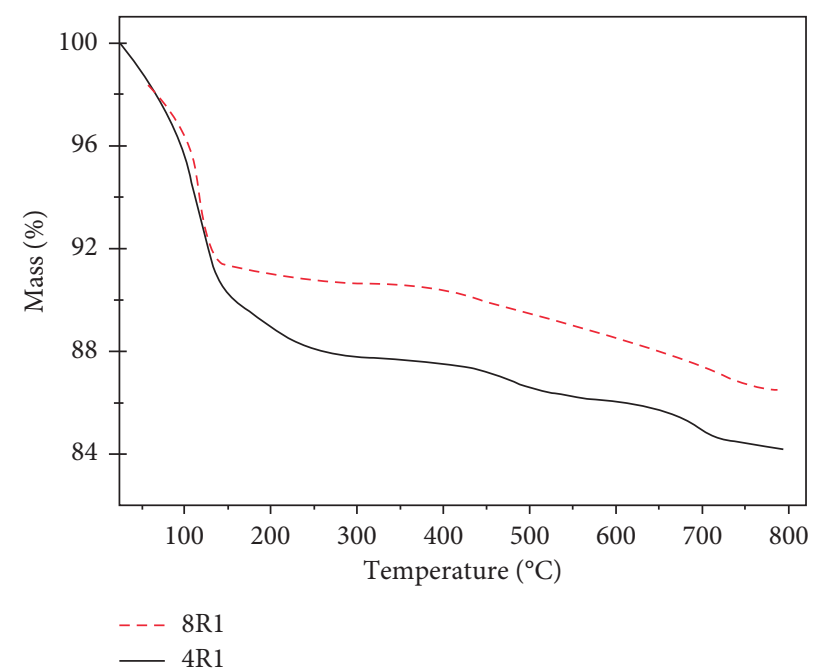

(a)

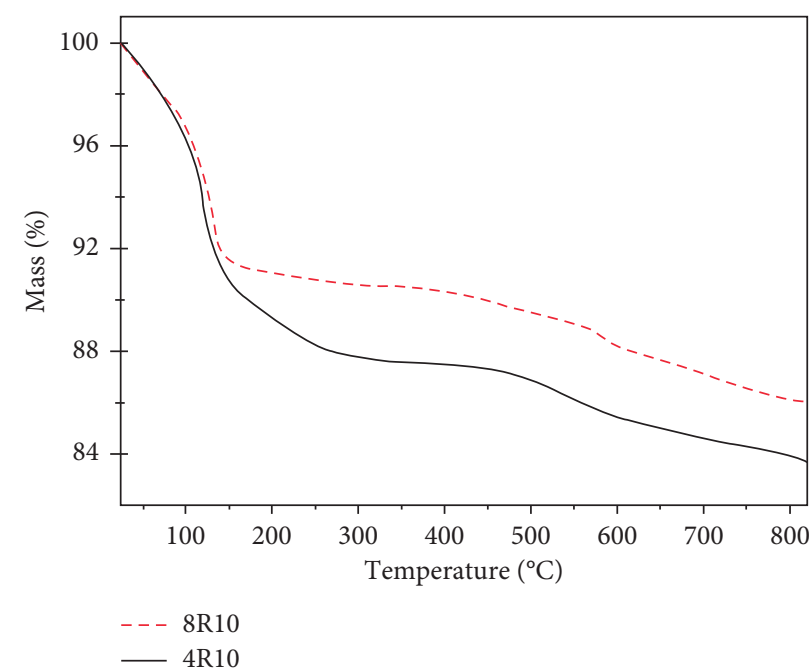

(b)

Figure 2: Thermograms for the materials synthesized at a heating rate of (a) $1^{\circ} \mathrm{C} / \mathrm{min}$ and (b) $10^{\circ} \mathrm{C} / \mathrm{min}$.

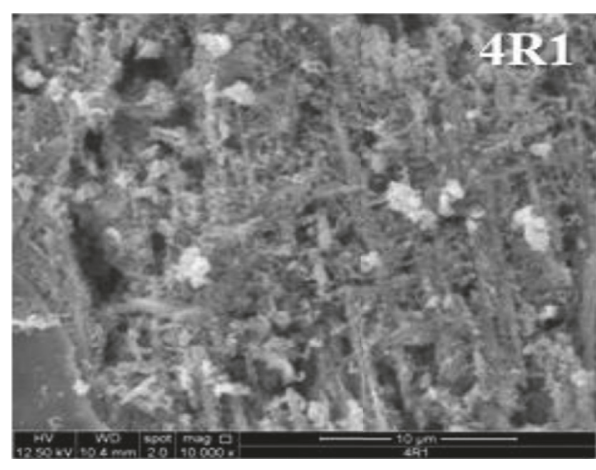

(a)

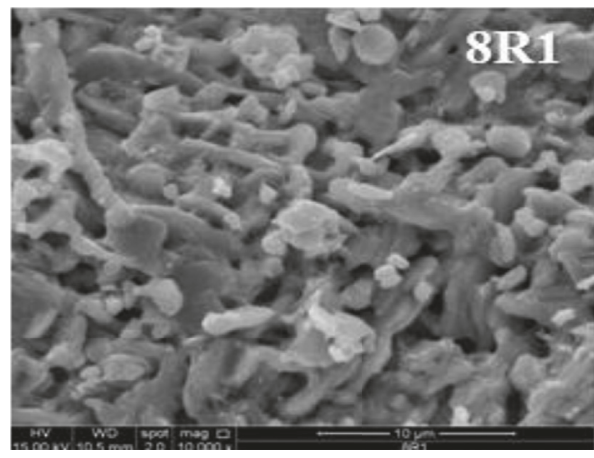

(c)

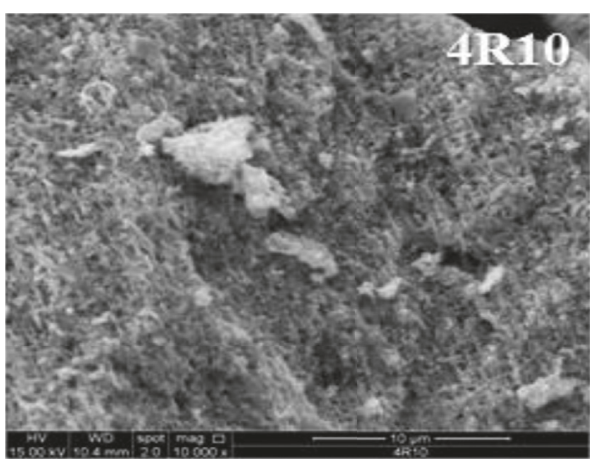

(b)

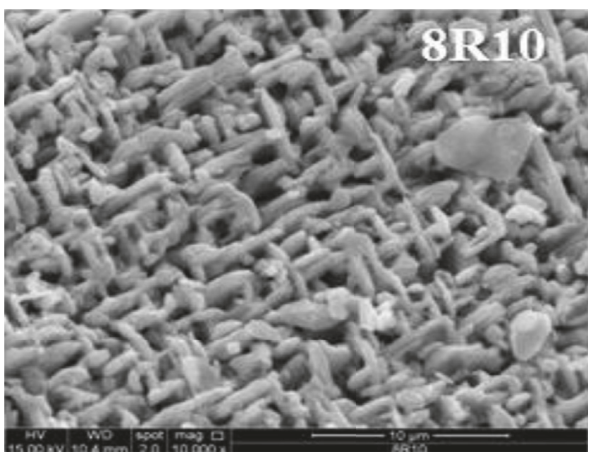

(d)

FIgURE 3: SEM micrographs of the materials synthesized at $400^{\circ} \mathrm{C}$ and $800^{\circ} \mathrm{C}$ and heating rates of $1^{\circ} \mathrm{C} / \mathrm{min}$ and $10^{\circ} \mathrm{C} / \mathrm{min}$ in both cases.

3.4. AC Conductivity at Room Temperature. The comparative study of the conductivity of synthesized materials (Figure 4) showed that those obtained at $10^{\circ} \mathrm{C} / \mathrm{min}$ had conductivities up to 1 order of magnitude higher than materials obtained at $1^{\circ} \mathrm{C} / \mathrm{min}$. In materials synthesized at $1^{\circ} \mathrm{C}$ and $10^{\circ} \mathrm{C} / \mathrm{min}$, the real component of the complex conductivity in the low-frequency region $\left(0.1 \mathrm{~Hz}\right.$ to $\left.10^{3} \mathrm{~Hz}\right)$ decreases as the synthesis temperature increases. Above $1000 \mathrm{~Hz}$, the conductivity depends more on the frequency, according to the
"Universal Johnscher's Law" [33], while at low frequencies, it is less dependent, which suggests DC conductivity. This phenomenon is similar to the one reported for birnessite synthesized by thermal reduction routes [2] and soft chemistry routes $[1,3]$. For frequencies up to $1 \times 10^{5} \mathrm{~Hz}$, in both sets of materials, $\sigma^{\prime}$ increases at lower temperature synthesis, and at higher frequencies, the conductivity become similar, having values in the range of semiconductors [34-36]. The increase in conductivity with the frequency 


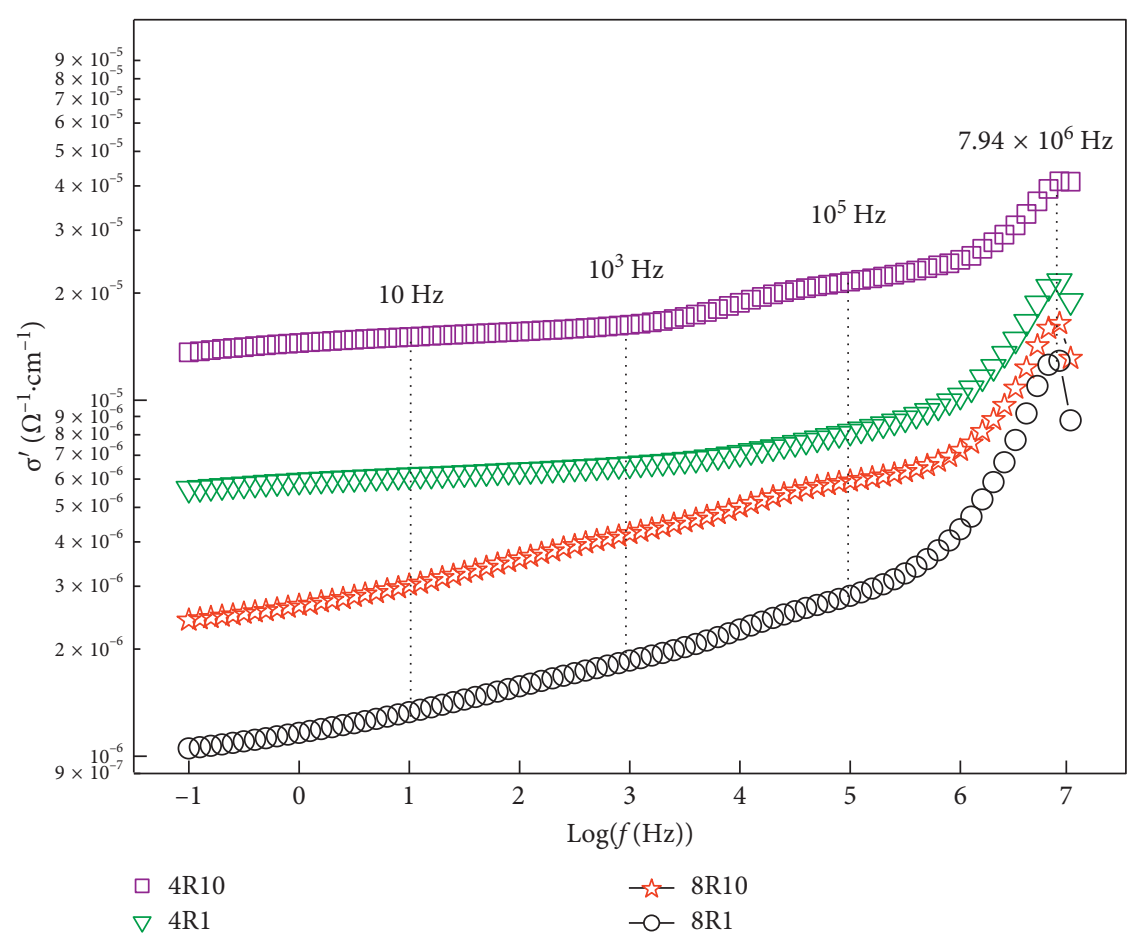

FIGURE 4: Effect of the synthesis temperature and the heating rate on the conductivity of the materials.

indicates a joint movement of charge carriers and changes in the conduction mechanisms $[1,2]$, mainly dominated by short-range conduction.

The conductivity as a function of the preparation temperature (Figure 4) showed that, at $400^{\circ} \mathrm{C}$, the materials were more conductive, thereby suggesting that the lamellar arrangement and the average oxidation state of manganese affect the conduction mechanisms as it was reported by Arias et al. $[1,2]$. On the contrary, the presence of $\mathrm{Mn}^{4+}$, understood as the amount of surface $\mathrm{Mn}^{4+}$ per nm of the crystal size (Table 1) as well as the stacking faults found by XRD (Figure 1), favors the electron "hopping" mechanism [1, 37] and therefore the electrical conduction. Moreover, the high heating rate used in the synthesis of these materials favors the generation of structural defects and microcracks [38] that modified the electrical conduction pathways. Also, both the variation in the lamellar ordering [24] and the birnessite crystal size alter this conduction routes. Consistent with the above, it was found that the conduction process was more favorable in $4 \mathrm{R} 10$. This material had the largest lamellar disorder, $\mathrm{Mn}^{4+}$ content, and the smallest crystal size.

3.5. Catalytic Degradation of Methylene Blue. With the aim to correlate the conductivity results with the catalytic performance, the catalytic degradation of methylene blue (MB) was used as the reaction model. Therefore, the synthesized materials were tested in the $\mathrm{MB}$ degradation reaction using hydrogen peroxide as an oxidizing agent. The $4 \mathrm{R} 10$ material exhibits the best performance in this reaction as it can be seen in Figure 5(a). This result was consistent with its highest conductivity (Figure 4), the content of $\mathrm{Mn}^{4+}$, and the smallest crystal size (Table 1) among all materials studied as it was discussed above. The literature reports that the materials with smaller crystal size exhibit better catalytic performance [38-41], which can be correlated with the increased surface area, necessary for reactions that occur mainly on the surface of the material $[28,39]$ like in those of MB degradation.

To study the maximal degradation of MB achieved by the $4 \mathrm{R} 10$ material, the reaction was monitored up to $1000 \mathrm{~min}$. Between 120 and $300 \mathrm{~min}$, the degradation percentage of $\mathrm{MB}$ was $10 \%$ higher than that obtained at 60 min (Figure 5(b)). At $600 \mathrm{~min}$, a $63.0 \%$ of degradation was reached. After 600 minutes, no significant increase was observed in the disappearance of $\mathrm{MB}$. When only $\mathrm{H}_{2} \mathrm{O}_{2}$ was used in the $\mathrm{MB}$ degradation, the percentage of the demise of $\mathrm{MB}$ was $9.3 \%$ at $120 \mathrm{~min}$ of reaction and $6.4 \%$ using only $4 \mathrm{R} 10$ (inset in Figure 5(b)), while the $\mathrm{MB}$ degradation with $4 \mathrm{R} 10$ in the presence of $\mathrm{H}_{2} \mathrm{O}_{2}$ was $50 \%$. These observations suggest that $\mathrm{MB}$ degradation occurs through the formation of reactive oxygen species (ROS) from $\mathrm{H}_{2} \mathrm{O}_{2}$ over $\mathrm{MnOx}$ such as $\mathrm{O}_{2}{ }^{\bullet-}$ and $\mathrm{OH}^{\bullet}[19,42,43]$. The formation of the $\mathrm{OH}^{\bullet}$ radical finally promotes the degradation of the organic dye until its complete mineralization and protonation of the peroxide $\mathrm{HO}_{2}{ }^{-}$anion which regenerates the $\mathrm{H}_{2} \mathrm{O}_{2}$, and it is shown as

$$
\begin{aligned}
& \mathrm{O}_{2}{ }^{--}+\mathrm{H}_{2} \mathrm{O} \longrightarrow \mathrm{OH}^{\bullet}+\mathrm{HO}_{2}{ }^{-} \\
& \mathrm{HO}_{2}{ }^{-}+\mathrm{H}^{+} \longrightarrow \mathrm{H}_{2} \mathrm{O}_{2}
\end{aligned}
$$

To elucidate if $\mathrm{O}_{2}{ }^{\bullet-}$ radical participate in this reaction, an additional experiment was done. It consisted of the addition of gallic acid, a scavenger specific for the radical $\mathrm{O}_{2}{ }^{--}$[44]. Figure 5(c) shows a reduction to $16.1 \%$ in the percentage of degradation of $\mathrm{MB}$ at 120 minutes of reaction. These results 


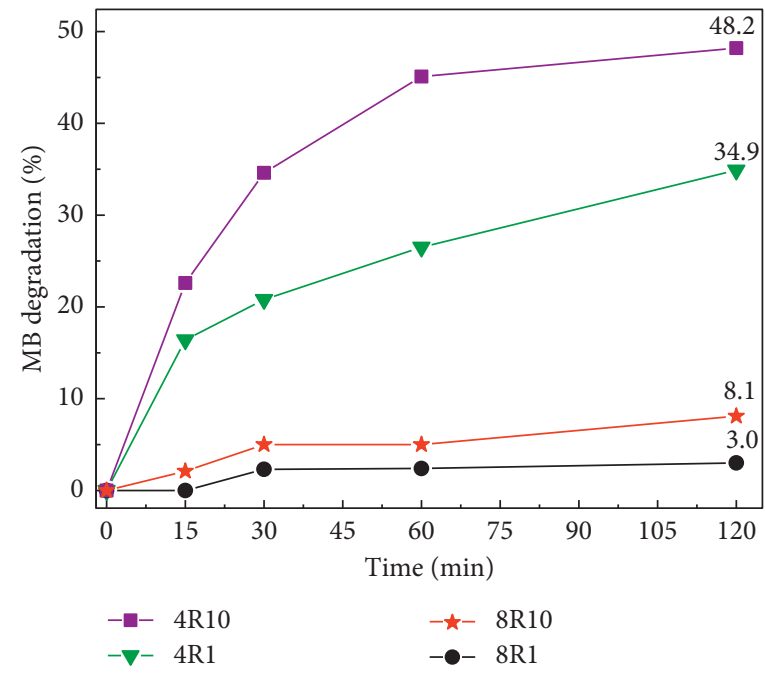

(a)

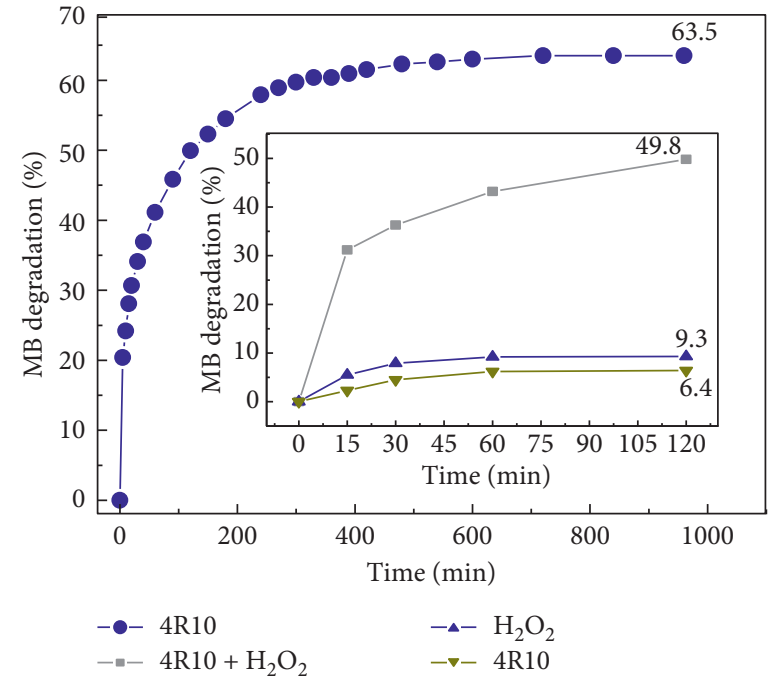

(b)

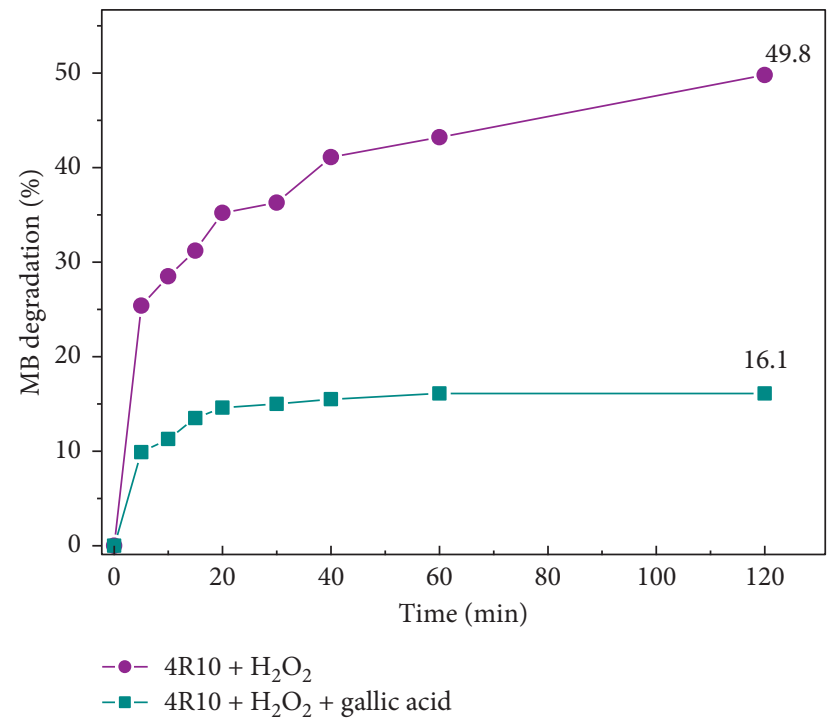

(c)

Figure 5: MB degradation. (a) Reactions using $\mathrm{H}_{2} \mathrm{O}_{2}$ as an oxidizing agent. (b) 4R10 material using $\mathrm{H}_{2} \mathrm{O}_{2}$ as an oxidizing agent. Insert: comparison with the reaction blanks up to $120 \mathrm{~min}$. (c) Effect of the gallic acid addition on the MB degradation for the $4 \mathrm{R} 10 \mathrm{material}$.

confirm the participation of these radicals in the mechanism of $\mathrm{MB}$ degradation.

\subsection{Proposed Mechanism Involving Electron Transfer.} Oxidative degradation of organic compounds, especially methylene blue, has been reported as a surface reaction that generates reactive oxygen species $[45,46]$. The oxidation of methylene blue through Fenton-type reactions involves the generation of free radicals from an oxidizing substance and from a material that can potentially provide electrons [45, 47]. In this case, hydrogen peroxide is decomposed by the manganese oxide to generate highly reactive oxygen species $[18,19,45,48]$.

The reaction between the birnessite and the hydrogen peroxide involves the adsorption of hydrogen peroxide over the material surface. The hydrogen peroxide should be adsorbed by an acid-Lewis site, with the $\mathrm{Mn}^{4+}$ being fundamental versus the
$\mathrm{Mn}^{3+}$ because of its most acidic characteristic. Finally, an electronic transfer from the hydrogen peroxide to the manganese (4+) led to the oxidation of the hydrogen peroxide to form a reactive oxygen species [19].

According to the results obtained in this study and considering the availability of $\mathrm{Mn}^{4+}$ in the surface of the material, Figure 6(a) shows the reaction mechanism for the formation of ROS from $\mathrm{H}_{2} \mathrm{O}_{2}$ and the layered material, mainly considering the presence of the $\mathrm{Mn}^{4+} / \mathrm{Mn}^{3+}$ [19] system. The described mechanism suggests acid-base reactions on the surface of the layered material, which has active sites of $\mathrm{Mn}^{4+}$. Initially, an acid-base reaction occurs between one of the oxygen molecules of $\mathrm{H}_{2} \mathrm{O}_{2}$ and $\mathrm{Mn}^{4+}$, followed by an electrostatic attraction between the hydrogen molecules of $\mathrm{H}_{2} \mathrm{O}_{2}$ and the layered material, which is well known to have a negative charge $[1,10]$. Once this 

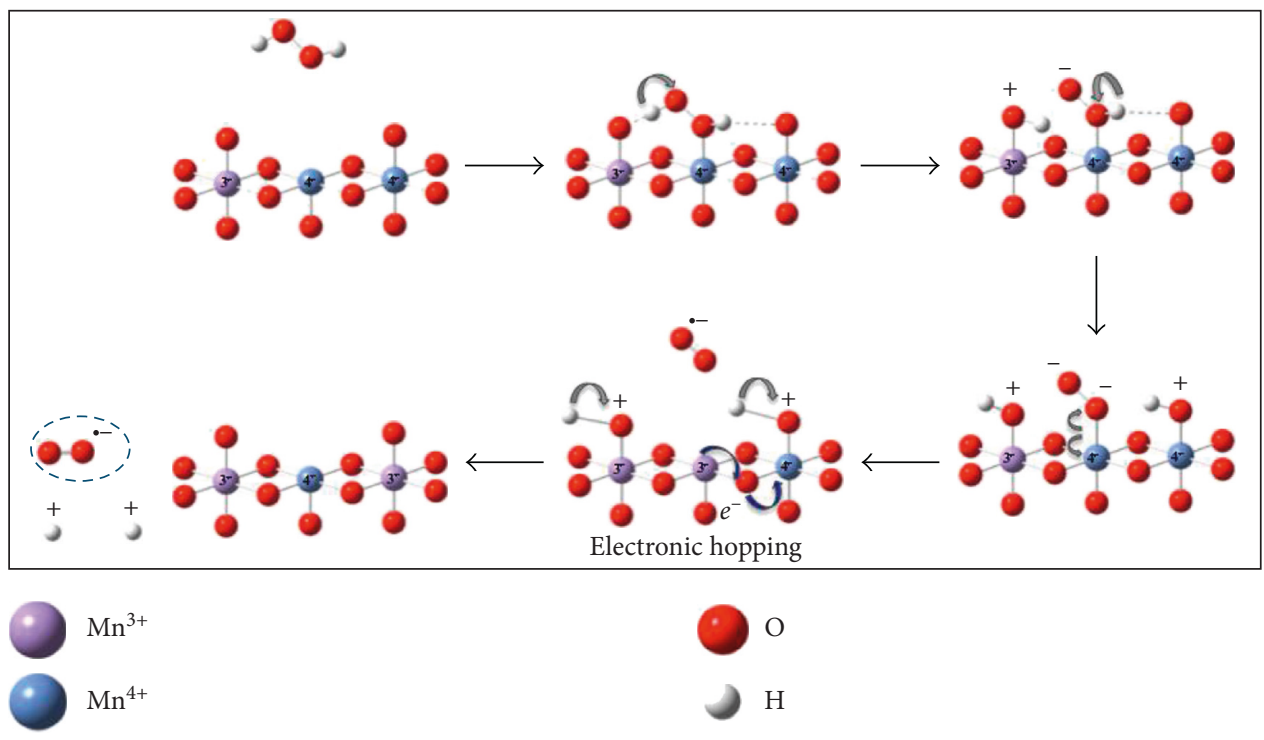

(a)

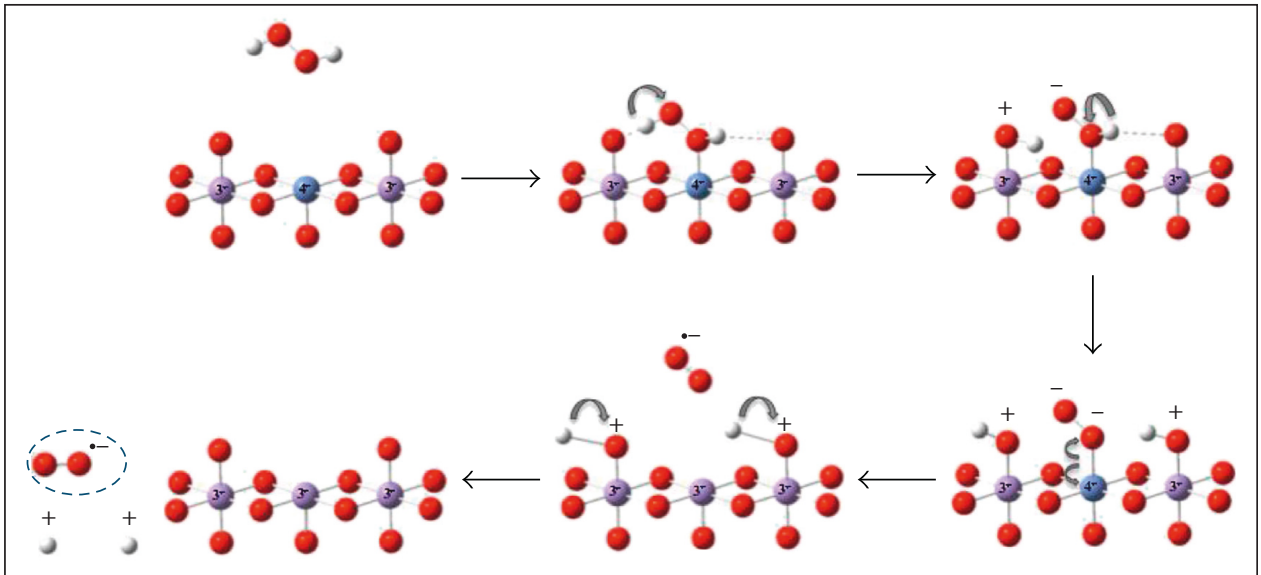
- $\mathrm{Mn}^{3+}$
C 0
- $\mathrm{Mn}^{4+}$
J $\mathrm{H}$

(b)

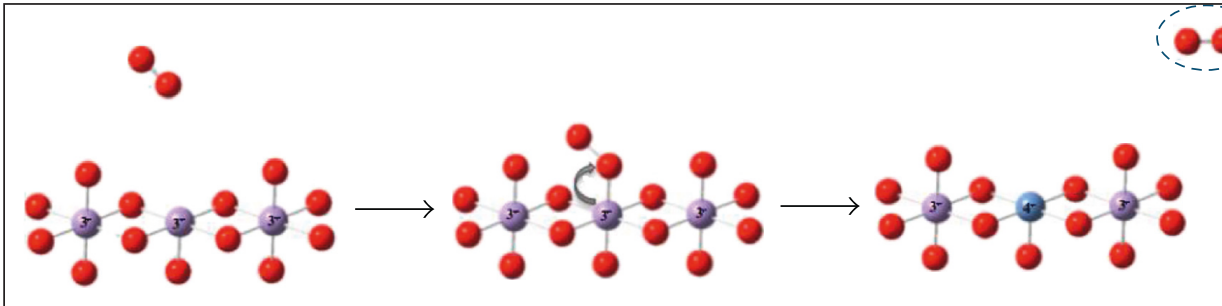

(1) $\mathrm{Mn}^{3+}$

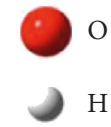

(c)

FIgURE 6: Continued. 


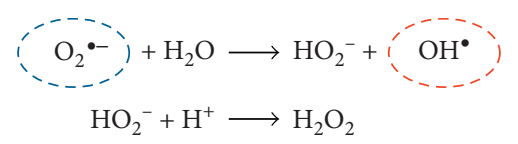

(d)

Figure 6: Proposed mechanism for the formation of the superoxide and hydroxyl radicals in MB degradation. (a) Hydrogen peroxide adsorption at an $\mathrm{Mn}^{4+}$ active site (oxygen vacant) with a posterior electron transfer to the $\mathrm{Mn}^{4+}$ active site and formation of a superoxide radical and an $\mathrm{Mn}^{3+}$ inactive site. There is an electron transfer process from an $\mathrm{Mn}^{3+}$ ion to an adjacent $\mathrm{Mn}^{4+}$ ion via an oxobridge (electronic hopping) to finally regenerate the $\mathrm{Mn}^{4+}$ active site. (b) A similar step as in (a) but in this case without regeneration of the active side. (c) Oxidation of $\mathrm{Mn}^{3+}$ with $\mathrm{O}_{2}$ at the oxygen vacant site to restore the $\mathrm{Mn}^{4+}$ active site and superoxide radical. (d) Formation of hydroxyl radical $\left(\mathrm{OH}^{\bullet}\right)$ and regeneration of hydrogen peroxide.

interaction is established, a homolytic rupture is suggested in the bond formed by $\mathrm{Mn}^{4+}$ and the oxygen of the peroxide, with the consequent reduction from $\mathrm{Mn}^{4+}$ to $\mathrm{Mn}^{3+}$ with the formation of the superoxide radical $\mathrm{O}_{2}{ }^{\bullet-}$. The original active site would be regenerated by the transfer of an electron from $\mathrm{Mn}^{3+}$, which has remained after the reaction, to an adjacent $\mathrm{Mn}^{4+}$ ion through the oxobridge, as illustrated in Figure 6(a). The electron transfer process from $\mathrm{Mn}^{3+}$ to $\mathrm{Mn}^{4+}$ via an oxobridge (electronic hopping) is well known in perovskite-type manganese oxides [49]. The described process should be facilitated in those materials, which have a higher electronic conductivity, thus helping to regenerate the active sites efficiently and thus increasing the catalytic activity of the material. It is suggested that this mechanism is most likely in materials with high oxidation state, that is, the highest content of $\mathrm{Mn}^{4+}$.

Another possible scenario would be given when the active sites of $\mathrm{Mn}^{4+}$ are adjacent only to $\mathrm{Mn}^{3+}$ ions. As shown in Figure 6(b), the reaction mechanism would be like that described above, except that the active sites that have been reduced to $\mathrm{Mn}^{3+}$ would no longer be so easily regenerated. For this purpose, it is proposed that an oxygen molecule can oxidize $\mathrm{Mn}^{3+}$ to $\mathrm{Mn}^{4+}$ and generate a superoxide radical, as it is illustrated in Figure 6(c). Finally, Figure 6(d) shows the reactions for the formation of hydroxyl radical from superoxide radical and the regeneration of hydrogen peroxide.

The proposed mechanism is consistent with experimental data and explains the trends found between conductivity, the average oxidation state of $\mathrm{Mn}$, and catalytic activity of the studied materials. Unlike mechanisms reported in the literature, this mechanism not only collects experimental observations but also considers explicitly the surface sites on which the reaction may be occurring, indicating the state of aggregation of the catalyst and the heterogeneous nature of the process.

\section{Conclusions}

We obtained birnessites whose conductivity differed significantly as a result of variations in the synthesis temperature and heating rate. A direct relationship between catalyst conductivity and $\mathrm{MB}$ degradation performance was observed. The 4R10 material which had a smaller crystal size, higher content of $\mathrm{Mn}^{4+}$, and higher conductivity showed the largest percentage of $\mathrm{MB}$ degradation. A general mechanism was proposed for understanding how manganese oxides behave as catalysts that produce oxidizing species from $\mathrm{H}_{2} \mathrm{O}_{2}$ that degrade methylene blue. Our proposed mechanism takes into consideration the following experimental observations: the availability of $\mathrm{Mn}^{4+}$, the electrical conductivity, and the heterogeneous nature of the process. This relationship can be useful and easy to apply for the design of heterogeneous catalysts for applications that are likely to spread beyond the studied reaction.

\section{Data Availability}

The data used to support the findings of this study are available from the corresponding author upon request.

\section{Conflicts of Interest}

The authors declare that there are no conflicts of interest regarding the publication of this paper.

\section{Acknowledgments}

The work at the Universidad Nacional de Colombia, Manizales Campus, was supported by Facultad de Ciencias Exactas y Naturales. The authors also acknowledge Laboratorio de Química (Atomic Absorption Analysis), Laboratorio de Magnetismo y Materiales Avanzados (Thermal and Calorimetric Analysis), and Laboratorio de Microscopia Electronica de Barrido (SEM) at the Universidad de Caldas. A. M. Suarez also acknowledges Facultad de Ciencias Exactas y Naturales, Universidad Nacional de ColombiaManizales, for a research internship.

\section{References}

[1] N. P. Arias, M. T. Dávila, and O. Giraldo, "Electrical behavior of an octahedral layered OL-1-type manganese oxide material," Ionics, vol. 19, no. 2, pp. 201-214, 2013.

[2] N. P. Arias, M. E. Becerra, and O. Giraldo, "Caracterización eléctrica de un óxido de manganeso laminar tipo birnesita," Revista Mexicana de Física, vol. 61, pp. 380-387, 2015.

[3] O. Giraldo, N. P. Arias, and M. E. Becerra, "Electrical properties of $\mathrm{TiO}_{2}$-pillared bidimensional manganese oxides," Applied Clay Science, vol. 141, pp. 157-170, 2017.

[4] Y. Tang, S. Zheng, Y. Xu, X. Xiao, H. Xue, and H. Pang, "Advanced batteries based on manganese dioxide and its composites,” Energy Storage Materials, vol. 12, pp. 284-309, 2018.

[5] H. R. Barai, A. N. Banerjee, and S. W. Joo, "Improved electrochemical properties of highly porous amorphous 
manganese oxide nanoparticles with crystalline edges for superior supercapacitors," Journal of Industrial and Engineering Chemistry, vol. 56, pp. 212-224, 2017.

[6] M. E. Becerra, N. P. Arias, O. H. Giraldo, F. E. López Suárez, M. J. Illán Gómez, and A. Bueno López, "Soot combustion manganese catalysts prepared by thermal decomposition of $\mathrm{KMnO}_{4}$," Applied Catalysis B: Environmental, vol. 102, no. 12, pp. 260-266, 2011.

[7] S. Dey, G. C. Dhal, D. Mohan, and R. Prasad, "Lowtemperature complete oxidation of $\mathrm{CO}$ over various manganese oxide catalysts," Atmospheric Pollution Research, vol. 9, no. 4, pp. 755-763, 2018.

[8] S. Das, A. Samanta, and S. Jana, "Light-assisted synthesis of hierarchical flower-like $\mathrm{MnO}_{2}$ nanocomposites with solar light induced enhanced photocatalytic activity," ACS Sustainable Chemistry and Engineering, vol. 5, no. 10, pp. 9086-9094, 2017.

[9] H. Xu, N. Yan, Z. Qu et al., "Gaseous heterogeneous catalytic reactions over Mn-based oxides for environmental applications: a critical review," Environmental Science and Technology, vol. 51, no. 16, pp. 8879-8892, 2017.

[10] S. L. Brock, N. Duan, Z. R. Tian, O. Giraldo, H. Zhou, and S. L. Suib, "A review of porous manganese oxide materials," Chemistry of Materials, vol. 10, no. 10, pp. 2619-2628, 1998.

[11] A. C. Thenuwara, S. L. Shumlas, N. H. Attanayake et al., "Intercalation of cobalt into the interlayer of birnessite improves oxygen evolution catalysis," ACS Catalysis, vol. 6, no. 11, pp. 7739-7743, 2016.

[12] J.-C. Wang, C.-X. Cui, Q.-Q. Kong et al., "Mn-doped g- $\mathrm{C}_{3} \mathrm{~N}_{4}$ nanoribbon for efficient visible-light photocatalytic water splitting coupling with methylene blue degradation," ACS Sustainable Chemistry and Engineering, vol. 6, no. 7, pp. 8754-8761, 2018.

[13] Y.-Y. Yang, M.-Q. He, M.-X. Li, Y.-Q. Huang, T. Chi, and Z.-X. Wang, "Ferrimagnetic copper-carboxyphosphinate compounds for catalytic degradation of methylene blue," Inorganic Chemistry Communications, vol. 94, pp. 5-9, 2018.

[14] G. Jayakumar, A. Albert Irudayaraj, and A. Dhayal Raj, "Photocatalytic degradation of methylene blue by nickel oxide nanoparticles," Materials Today: Proceedings, vol. 4, no. 11, pp. 11690-11695, 2017.

[15] L. Wolski, A. Walkowiak, and M. Ziolek, "Formation of reactive oxygen species upon interaction of $\mathrm{Au} / \mathrm{ZnO}$ with $\mathrm{H}_{2} \mathrm{O}_{2}$ and their activity in methylene blue degradation," Catalysis Today, 2018, In press.

[16] Z. M. Abou-Gamra and M. A. Ahmed, "Synthesis of mesoporous $\mathrm{TiO}_{2}$-curcumin nanoparticles for photocatalytic degradation of methylene blue dye," Journal of Photochemistry and Photobiology B: Biology, vol. 160, pp. 134-141, 2016.

[17] F. Azeez, E. Al-Hetlani, M. Arafa et al., "The effect of surface charge on photocatalytic degradation of methylene blue dye using chargeable titania nanoparticles," Scientific Reports, vol. 8, no. 1, p. 7104, 2018.

[18] T. Sriskandakumar, N. Opembe, C.-H. Chen, A. Morey, C. King'ondu, and S. L. Suib, "Green decomposition of organic dyes using octahedral molecular sieve manganese oxide catalysts," Journal of Physical Chemistry A, vol. 113, no. 8, pp. 1523-1530, 2009.

[19] L. Zhang, Y. Nie, C. Hu, and X. Hu, "Decolorization of methylene blue in layered manganese oxide suspension with $\mathrm{H}_{2} \mathrm{O}_{2}$," Journal of Hazardous Materials, vol. 190, no. 1-3, pp. 780-785, 2011.

[20] I. A. Salem and M. S. El-Maazawi, "Kinetics and mechanism of color removal of methylene blue with hydrogen peroxide catalyzed by some supported alumina surfaces," Chemosphere, vol. 41, no. 8, pp. 1173-1180, 2000.

[21] D. Glover, B. Schumm, and A. Kozowa, Handbook of Manganese Dioxides Battery Grade, International Battery Materials Association, Cleveland, OH, USA, 1989.

[22] L. Alexander and H. P. Klug, "Determination of crystallite size with the X-ray spectrometer," Journal of Applied Physics, vol. 21, no. 2, pp. 137-142, 1950.

[23] A.-C. Gaillot, D. Flot, V. A. Drits, A. Manceau, M. Burghammer, and B. Lanson, "Structure of synthetic K-rich birnessite obtained by high-temperature decomposition of $\mathrm{KMnO}_{4}$. I. Two-layer polytype from $800^{\circ} \mathrm{C}$ experiment," Chemistry of Materials, vol. 15, no. 24, pp. 4666-4678, 2003.

[24] V. A. Drits, B. Lanson, and A.-C. Gaillot, "Birnessite polytype systematics and identification by powder X-ray diffraction," American Mineralogist, vol. 92, no. 5-6, pp. 771-788, 2007.

[25] V. A Drits, E. Silvester, A. Gorshkov, and A. Manceau, "Structure of synthetic monoclinic Na-rich birnessite and hexagonal birnessite: I. Results from X-ray diffraction and selected-area electron diffraction," American Mineralogist, vol. 82, no. 9-10, pp. 946-961, 1997.

[26] C.-H. Chen and S. L. Suib, "Control of catalytic activity via porosity, chemical composition, and morphology of nanostructured porous manganese oxide materials," Journal of the Chinese Chemical Society, vol. 59, no. 4, pp. 465-472, 2012.

[27] H.-J. Cui, J.-W. Shi, and M.-L. Fu, "Synthesis, and catalytic activity of magnetic cryptomelane-type manganese oxide nanotubes," Journal of Cluster Science, vol. 23, no. 3, pp. 607-614, 2012.

[28] Y.-C. Son, V. D. Makwana, A. R. Howell, and S. L. Suib, "Efficient, catalytic, aerobic oxidation of alcohols with octahedral molecular sieves," Angewandte Chemie International Edition, vol. 40, no. 22, pp. 4280-4283, 2001.

[29] M. Ilyas, M. Saeed, M. Sadiq, and M. Siddique, "Mixedvalence manganese oxide catalysed oxidation of benzyl alcohol and cyclohexanol in the liquid phase," Progress in Reaction Kinetics and Mechanism, vol. 39, no. 4, pp. 375-390, 2014.

[30] W. Yang, J. Zhang, Q. Ma, Y. Zhao, Y. Liu, and H. He, "Heterogeneous reaction of $\mathrm{SO}_{2}$ on manganese oxides: the effect of crystal structure and relative humidity," Scientific Reports, vol. 7, no. 1, p. 4550, 2017.

[31] A.-C. Gaillot, V. A. Drits, A. Manceau, and B. Lanson, "Structure of the synthetic K-rich phyllomanganate birnessite obtained by high-temperature decomposition of $\mathrm{KMnO}_{4}$ : substructures of K-rich birnessite from $1000^{\circ} \mathrm{C}$ experiment," Microporous and Mesoporous Materials, vol. 98, no. 1-3, pp. 267-282, 2007.

[32] A. Ecija, K. Vidal, A. Larrañaga, L. Ortega-San-Martín, and M. I. Arriortua, "Synthetic methods for perovskite materials; structure and morphology," in Advances in Crystallization Processes, Y. Mastai, Ed., pp. 485-506, InTech, Den Haag, Netherlands, 2012, https://www.intechopen.com/books/ advances-in-crystallization-processes/synthetic-methods-forperovskite-materials-structure-and-morphology.

[33] A. K. Jonscher, "The 'universal' dielectric response," Nature, vol. 267, no. 5613, pp. 673-679, 1977.

[34] D. M. Sherman, "Electronic structures of iron(III) and manganese(IV) (hydr)oxide minerals: thermodynamics of photochemical reductive dissolution in aquatic environments," Geochimica et Cosmochimica Acta, vol. 69, no. 13, pp. 3249-3255, 2005.

[35] H. Sato, J.-I. Yamaura, T. Enoki, and N. Yamamoto, "Magnetism and electron transport phenomena of manganese 
oxide ion exchanger with tunnel structure," Journal of Alloys and Compounds, vol. 262-263, pp. 443-449, 1997.

[36] R. N. De Guzman, A. Awaluddin, Y.-F. Shen et al., "Electrical resistivity measurements on manganese oxides with layer and tunnel structures: birnessites, todorokites, and cryptomelanes," Chemistry of Materials, vol. 7, no. 7, pp. 1286-1292, 1995.

[37] C. Stampfl and C. G. Van de Walle, "Energetics and electronic structure of stacking faults in AlN, GaN, and InN," Physical Review B, vol. 57, no. 24, pp. R15052-R15055, 1998.

[38] F. Schüth, "General principles for synthesis and modification of porous materials," in Handbook of Porous Solids, Wiley, Berlin, Germany, 2002.

[39] S. L. Suib, "Structure, porosity, and redox in porous manganese oxide octahedral layer and molecular sieve materials," Journal of Materials Chemistry, vol. 18, no. 14, pp. 1623-1631, 2008.

[40] J. Mondal, Q. T. Trinh, A. Jana et al., "Size-dependent catalytic activity of palladium nanoparticles fabricated in porous organic polymers for alkene hydrogenation at room temperature," ACS Applied Materials and Interfaces, vol. 8, no. 24, pp. 15307-15319, 2016.

[41] A. Singh, R. K. Hocking, S. L. Y. Chang et al., "Water oxidation catalysis by nanoparticulate manganese oxide thin films: probing the effect of the manganese precursors," Chemistry of Materials, vol. 25, no. 7, pp. 1098-1108, 2013.

[42] H. Zhou, Y. F. Shen, J. Y. Wang, X. Chen, C.-L. O'Young, and S. L. Suib, "Studies of decomposition of $\mathrm{H}_{2} \mathrm{O}_{2}$ over manganese oxide octahedral molecular sieve materials," Journal of $\mathrm{Ca}$ talysis, vol. 176, no. 2, pp. 321-328, 1998.

[43] W. Zhang, H. Wang, Z. Yang, and F. Wang, "Promotion of $\mathrm{H}_{2} \mathrm{O}_{2}$ decomposition activity over $\beta-\mathrm{MnO}_{2}$ nanorod catalysts," Colloids and Surfaces A: Physicochemical and Engineering Aspects, vol. 304, no. 1-3, pp. 60-66, 2007.

[44] A. G. Couto, C. A. L. Kassuya, J. B. Calixto, and P. R. Petrovick, "Anti-inflammatory, antiallodynic effects and quantitative analysis of gallic acid in spray dried powders from Phyllanthus niruri leaves, stems, roots and whole plant," Revista Brasileira de Farmacognosia, vol. 23, no. 1, pp. 124131, 2013.

[45] K. Dutta, S. Mukhopadhyay, S. Bhattacharjee, and B. Chaudhuri, "Chemical oxidation of methylene blue using a Fenton-like reaction," Journal of Hazardous Materials, vol. 84, no. 1, pp. 57-71, 2001.

[46] A. K. M. Atique Ullah, A. K. M. Fazle Kibria, M. Akter, M. N. I. Khan, A. R. M. Tareq, and S. H. Firoz, "Oxidative degradation of methylene blue using $\mathrm{Mn}_{3} \mathrm{O}_{4}$ nanoparticles," Water Conservation Science and Engineering, vol. 1, no. 4, pp. 249-256, 2017.

[47] Y. Zhang, J. Shang, Y. Song et al., "Selective Fenton-like oxidation of methylene blue on modified Fe-zeolites prepared via molecular imprinting technique," Water Science and Technology, vol. 75, no. 3, pp. 659-669, 2017.

[48] K. M. Kwon, I. G. Kim, Y.-S. Nam et al., "Catalytic decomposition of hydrogen peroxide aerosols using granular activated carbon coated with manganese oxides," Journal of Industrial and Engineering Chemistry, vol. 62, pp. 225-230, 2018.

[49] A. S. Bhalla, R. Guo, and R. Roy, "The perovskite structure-a review of its role in ceramic science and technology," $M a$ terials Research Innovations, vol. 4, no. 1, pp. 3-26, 2000. 


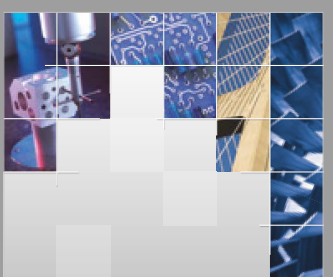

\section{Enfincering}
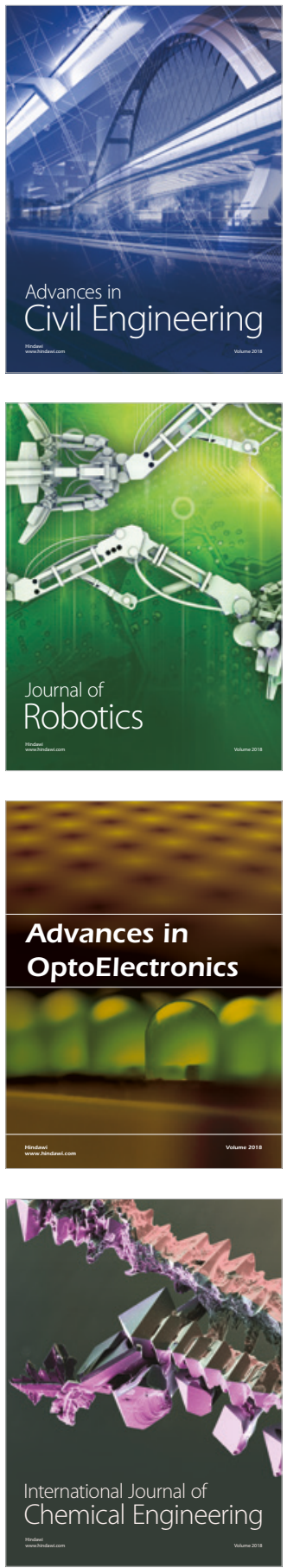

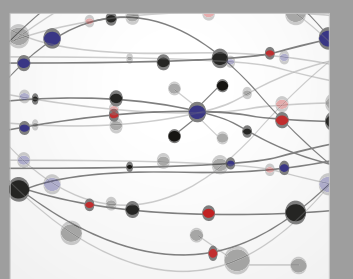

\section{Rotating \\ Machinery}

The Scientific World Journal

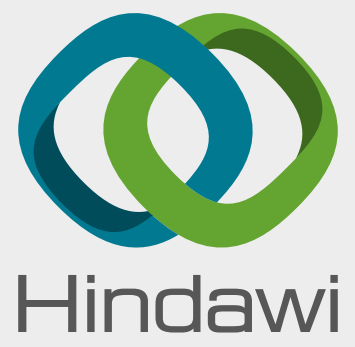

Submit your manuscripts at

www.hindawi.com
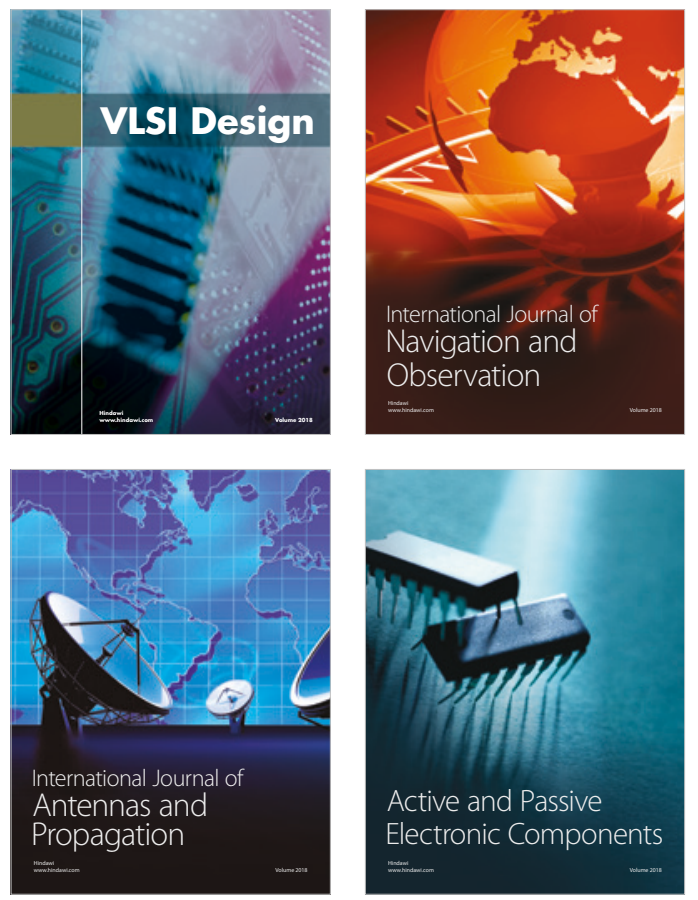
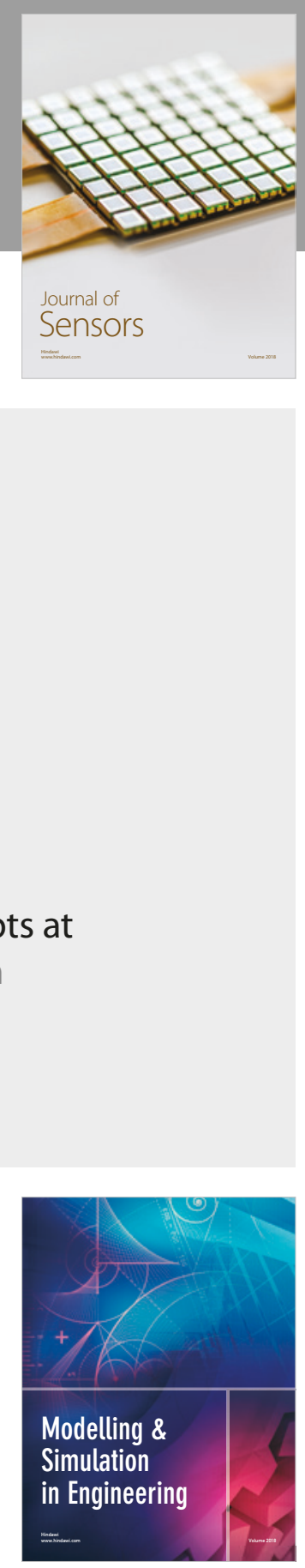

\section{Advances \\ Multimedia}
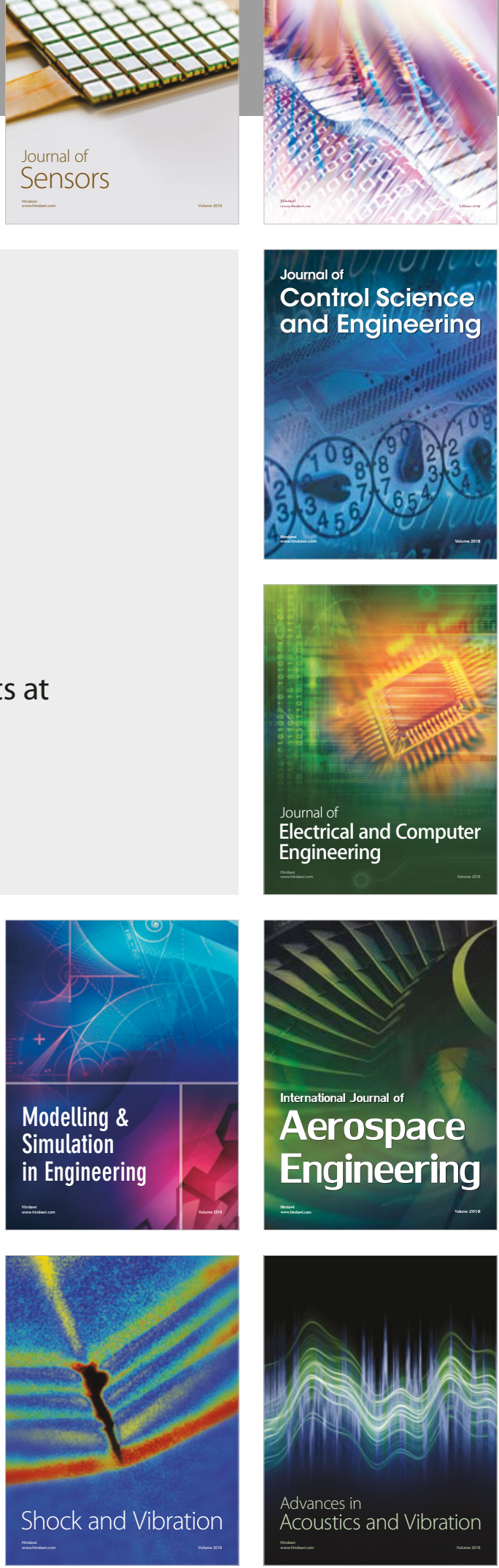